\title{
BETWEEN IT AND SOCIETAL SHIFT: PRECONDITIONS OF OPEN STRATEGIZING
}

\author{
Alina Kozarkiewicz \\ AGH University of Science and Technology, Cracow, Poland \\ ORCID: 0000-0002-0683-3148; e-mail: akozarki@zarz.agh.edu.pl \\ (C) 2018 Alina Kozarkiewicz \\ This is an open access article distributed under the Creative Commons Attribution-NonCommercial-NoDerivs license \\ (http://creativecommons.org/licenses/by-nc-nd/3.0/)
}

DOI: $10.15611 / \mathrm{ms} .2018 .4 .01$

\begin{abstract}
The main aim of this paper is to indicate and analyse the primary conditions needed to implement the concept of open strategizing into the practice of an organization, as well as to make it successful. The structure of the paper comprises two main parts: a brief introduction to the most important issues of open strategy is followed by the results of own research. Two major approaches towards the notion of open strategy are delineated: the first is more oriented towards strategy content and based on the idea of comprising collaborative initiatives into a firm's strategic plans, and the second refers to strategic management process, based on including external and internal actors (stakeholders) into strategizing processes. Within own research based on literature review and the re-reading of case materials, four categories of preconditions of open strategizing are revealed. These categories, described and illustrated by examples, comprise: level and quality of social IT implementation, open culture and leadership, capabilities and competences, as well as the perceived expected benefits from inclusion and transparency.
\end{abstract}

Keywords: open innovations, open strategy, transparency, inclusion, social media.

\section{Introduction}

In recent years extended discussions concerning new trends in modern management and the challenges facing managers of contemporary organizations have been triggered repeatedly [Hamel 2009]. What is explored are new demands related to dynamic, unpredictable and disruptive technological changes, new demographical and/or social phenomena, as well as new expectations and requirements of employees. When analysing contemporary discourses on management, undoubtedly such notions as adaptiveness, agility and openness are encountered constantly. The last seems to have become more and more popular, as the idea of openness has given rise to numerous concepts, or even social movements, such as open innovation, open government, open science and open software development. Moreover, openness lays the foundations for the development of crowdsourcing (as well as crowdfunding, crowdvoting, crowdsolving, etc.) or a sharing economy. Similarly, strategic management 'has been opened to openness' encompassing the conception of an open strategy.
Open strategy or open strategizing are based on the idea of open innovation. The term appeared in the work of the author and promoter of open innovation, H.W. Chesbrough [Chesbrough, Appleyard 2007], and then was propagated and widely publicized by many researchers, including $\mathrm{R}$. Whittington [Whittington et al. 2011; Whittington 2015] and G. Szulanski [Mack, Szulanski 2017]. In general, open strategy is about making strategy inclusive and transparent. More precisely, there are two major approaches towards the notion of open strategy: the first is more oriented towards strategy content and based on the idea of comprising collaborative initiatives into a firm's strategic plans [Chesbrough, Appleyard 2007; Appleyard, Chesbrough 2017], and the second refers to the strategic management process, based on including external and internal actors (stakeholders) into strategizing processes [Whittington et al. 2011; Whittington 2015; Tavakoli et al. 2017].

The decade of the research on open strategy induced the investigation into framework and outlines of this broad notion. Moreover, the breadth of prior 
research allows the exploration and exploitation of numerous case studies demonstrated so far. As the analysis reveals, open strategy has been implemented into the practice of various organizations - from large corporations such as IBM and Siemens, through to the army, and even charities. However, as is evident, not all organizations are inclined to implement this idea into their reality. Thus the research problem of this paper concerns the contingencies fostering open strategizing in an organization: what are the major preconditions for the introduction of open strategy principles?

The paper is based on the literature review and prior research, specifically focusing on existing case studies as the secondary source of data. Firstly, a brief introduction of the concept of open strategy is presented. Next, the results of research on the most important preconditions of open strategy are debated and illustrated. In the final discussion, the theoretical and practical implication are delineated briefly.

\section{Open strategy}

For years researchers in the field of strategic management have been pointing at the fact that strategy, when regarded as a process or an outcome of social interactions, requires shared beliefs and understandings, therefore the greater involvement of middle managers in strategy formulation could be a way to create stronger commitment or more effective strategy implementation [Collier et al. 2004; Mantere, Vaara 2008]. Thus, so called bottom-up strategizing has encountered numerous supporters and promotors. Currently such phenomena as openness, inclusiveness, transparency, democracy and common understanding are regarded as important components of a successful strategic management process, and the term 'open strategy' since the beginning, has met with a lot of interests and attracted numerous supporters.

According to prior research, open strategy builds directly on the notion of open innovation, and many drivers or enablers of open innovation are reflected in opening up strategies. As mentioned above, the term open strategy was introduced by H.W. Chesbrough and M.M. Appleyard [2007] and next developed into two streams of thought termed: 'content branch' and 'process branch' [Appleyard, Chesbrough 2017]. The content branch is based on the approach encoraged by H.W. Chesbrough, his colleagues and followers, and it focuses on the content or entity view of open strategy - understood as a firm's rationale for access to an open initiative, e.g. innovation networks. According to the definition coherent with this view, open strategy is a firm's justification for participating in an open initiative, including its ability to capture value from the enterprise [Appleyard, Chesbrough 2017]. An open initiative is characterized by the reliance on assets outside of the firm's boundaries (inclusion), and free access to the project results by outsiders (transparency).

The process branch relates to the process or practical view of strategy [Whittington et al. 2011; Whittington 2015; Hautz et al. 2017; Tavakoli et al. 2017; Yakis-Douglas et al. 2017], and sees open strategy as a way to enhance the strategy development process by widening the participation of both internal and external actors, as well as improving the transparency of strategy ${ }^{1}$. One of the most often cited definitions of open strategy within this approach says that it is an emerging information technology which enabled strategizing practice in which organisations involve large numbers of internal or external actors, improving transparency inside and outside of the firm [Whittington et al. 2011]. A similar definition perceives open strategy as a practice that involves upper echelon ${ }^{2}$ and non-upper-echelon organisational members as well as stakeholders from outside the organisation; practitioners of open strategy draw upon sets of both traditional strategizing practices as well as open practices (transparent discourse, co-creation and democratic decision making). The latter set of practices is based on the norms of inclusiveness and transparency and is enabled by IT [Tavakoli et al. 2017].

It is noteworthy that the idea of open strategy is completely different from traditional top-level strategizing and significantly different from bottom-up strategizing. Top-level strategizing is mostly secretive, non-inclusive and controlled by the organisation's upper echelon, and bottom-up strategizing refers mostly to the involvement of middle management or selected groups of employees from lower organisational levels [Mantere, Vaara 2008; Tavakoli et al. 2017]. What constitutes open strategy is overall transparency, wide inclusiveness, the extensive use of social IT, and the mass participation of employees and stakeholders [Whittington et al. 2011; Dobusch, Müller-Seitz 2012; Stieger et al. 2012; Amrollahi, Ghapnchi 2016; Dobusch, Kapeller 2017]. Open strategy can be seen as a particular form of IT-enabled crowdsourcing [Malhotra et al. 2017]. What is particularly important is the greater openness in

\footnotetext{
${ }^{1}$ It must be underlined that this paper is aligned with this approach (processual school of thought) and aims to contribute to this line of academic debate.

${ }^{2}$ Elite group of senior executives.
} 
strategizing resulting in the dissolution of organizational boundaries or hierarchies, as well as in the societal shift towards egalitarianism and common engagement [Whittington at al. 2011].

The existing research on the concept as well as the practice of open strategy enables to recognize multiple ways of 'opening' the strategic management process, e.g. strategy jamming [Bjelland, Wood 2008] - deals with the inclusion of a greater number of internal employees by using social media technologies, interorganisational strategizing [Whittington at al. 2011] - takes place through the organisation of strategy workshops between different firms, external openness [Gegenhuber, Dobusch 2017] - can be achieved through media strategy presentations and more comprehensive strategy reporting, and collective strategy processes [Heracleous et al. 2018] - is community-based or network-based venture.

Currently, open strategy is the subject of investigations offering many intriguing research questions. The high level of research interest is evident in the dedicated panels, online workshop communities, conference tracks and journal special issues of journals [Tavakoli et al. 2017]. It should be noted, however, that the literature research uncovers numerous similar concepts existing under various names, such as: 'co-creating strategy' meaning the involvement of various actors in strategy formulation [Ramaswamy, Ozcan 2013], 'democratic strategy', i.e. democratising strategy formulation and making it more open, and consultative for all involved stakeholders [Stieger et al. 2012], 'collaborative strategic planning', 'strategy jamming', 'inter-organizational strategizing' [Whittington et al. 2011], 'massification of strategy' [Whittington 2015], 'open-source strategy' [Newstead, Lanzerotti 2010], 'participatory strategy processes' highlighting the crucial participation and contribution of external actors, and 'strategy as a practice of thousands' [Dobusch, Müller-Seitz 2012].

\section{Research method}

In this research, prior studies on open strategy have been explored through the systematic literature review of publications in selected databases: Wiley Online, ScienceDirect (Elsevier) ABI/INFORM (ProQuest) and EmeraldInside. In the search processes the following expressions: open strateg*, bottom-up strateg*, democra* strateg*, participa* strateg*, collaborat* strategy*, as well as conjunctions of strateg* and Web 2.0 also Enterprise 2.0 were used, and papers published after 2007 were investigated. After that stage the bibliography of selected articles was taken into consideration. As was revealed, although the number of papers fulfilling the criteria was abundant (a few hundred), the assessment of the relevance, the access to full papers, and the quality of publications resulted in a set of 43 papers. In the last stage of the research, particular focus was placed on the case studies published in prior works, and finally, after analyses of the content, a range of 21 cases or vignettes was collected.

A brief analysis of the cases demonstrated that open strategizing was applied by various organizations, for example corporations such as IBM [Bjelland, Wood 2008], small firms or new ventures [Gegenhuber, Dobusch 2017], financial institutions [Tavakoli et al. 2017], public institutions, such as universities [Amrollahi, Rowlands 2017], research centres [Malhotra et al. 2017], the army [Aten, Thomas 2016], or third sector organizations such as charities [Heracleous et al. 2018]. The extension of size, sectors, and geographic areas indicates that open strategy is a universal concept, however not all organizations are keen to introduce more open strategic processes. This confirms the relevance of the research problem and makes the question of open strategy preconditions significant for the theory and practice of contemporary strategic management.

\section{Research results and discussion}

Reflection on the prior research with a particular focus on the case materials allows to explore the meaningful preconditions or enablers of open strategy. As predicted, there are common external premises, such as the development of IT and social media creating supporting circumstances to social openness, and thus to open strategizing. However at the core of this research there were specific internal prerequisites creating a particular entourage for organizations to be more progressive and encouraged in promoting openness in strategic processes. Although there are numerous circumstances supporting open strategizing, to make the arguments more pronounced, it seems to be justifiable to assemble them into four major categories:

1. The extent and quality of social IT and Web 2.0 (Enterprise 2.0] practices in the organization, common and regular usage of Web 2.0 for internal communication;

2. Open environment, and especially organizational culture oriented towards such values as democracy, equality, inclusion and transparency, open and engaging leadership linked with decentralized structures;

3. Capabilities and competences, both individual and organizational, with a particular focus on 
innovation management (e.g. absorptive capacity or project management competences) and communication;

4. Perception of expected benefits from openness, inclusions, and transparency.

The established categories of the preconditions of open strategizing have been confirmed by re-reading case materials, as illustrated in Table 1.

Obviously the advancements in social media technologies are revolutionizing communication processes and changing social interactions, first of all by allowing the inclusion of employees and more transparent communication. The internal usage of Web 2.0 technologies have the potential to enhance strategy formation - coordination and collaboration, knowledge sharing and problem solving, as well as the exchange of the potential content of new strategy. The active use of social media could make the vision of senior management more transparent, and could bring support and feedback from firm's employees,

Table 1. Preconditions of open strategizing - case illustrations

\begin{tabular}{|c|c|c|c|}
\hline No. & Preconditions & $\begin{array}{c}\begin{array}{c}\text { Examples of case study } \\
\text { research }\end{array} \\
\end{array}$ & Illustration/verification \\
\hline \multirow[t]{2}{*}{1} & \multirow[t]{2}{*}{$\begin{array}{l}\text { Web } 2.0 \\
\text { implementation }\end{array}$} & $\begin{array}{l}\text { IBM - strategic jamming to } \\
\text { promote innovations } \\
{[\text { Bjelland, Wood 2008] }}\end{array}$ & $\begin{array}{l}\text { "Jam" was IBM's term for a "massively parallel conference" online, i.e. a group of } \\
\text { interlinked bulletin boards and related Web pages on IBM's intranet. The systems } \\
\text { for centrally managing and seeking answers to important questions would give } \\
\text { people a sense of participation and of being listened to, as well as generate valuable } \\
\text { new ideas (p. 32). "Jam" demonstrated that online conversations and sophisticated } \\
\text { technology can bring those ideas to bear on important societal problems (p. 33). }\end{array}$ \\
\hline & & $\begin{array}{l}\text { Naval Air Warfare Center } \\
\text { Aircraft Division - crowd- } \\
\text { sourcing platform to support } \\
\text { strategy communication } \\
\text { [Aten, Thomas 2016] }\end{array}$ & $\begin{array}{l}\text {... approval to use the MMOWGLI-crowdsourcing platform to update the } \\
\text { strategic plan. MMOWGLI provides a space for large and diverse groups of } \\
\text { people to work together on idea generation and action planning. It resulted in a } \\
\text { rich database of postings and reports that documented the entire play, including } \\
\text { idea chains and action plans (pp.12-15). Crowdsourcing technology afforded } \\
\text { individual and collective actions ... constituted strategy communication flows } \\
\text { and potential discursive resources that differed from those constituted in } \\
\text { traditional strategizing (p. 16). }\end{array}$ \\
\hline \multirow[t]{2}{*}{2} & \multirow[t]{2}{*}{$\begin{array}{l}\text { Open culture } \\
\text { and leadership }\end{array}$} & $\begin{array}{l}\text { Wikimedia - the board } \\
\text { supporting collective and } \\
\text { transparent actions } \\
{[\text { Heracleous et al. 2018] }}\end{array}$ & $\begin{array}{l}\text {... the board decided to take a fresh approach to strategy-making, drawing on the } \\
\text { principles of building a transparent, collective vision, open collaboration, and } \\
\text { stakeholder involvement. "We believe that people who want to have a voice in } \\
\text { the process, should be heard" (pp. 13-14). }\end{array}$ \\
\hline & & $\begin{array}{l}\text { Premium Cola - collective } \\
\text { actions as an element of } \\
\text { mission } \\
\text { [Luedicke et al. 2017] }\end{array}$ & $\begin{array}{l}\text { It deliberately takes open strategizing to an extreme in all the three domains of } \\
\text { open strategizing. From its inception, Premium members decided to run their } \\
\text { operations as a "collective" and to develop and continuously update a catalogue } \\
\text { of ethical business rules that they call their "operating system". The operating } \\
\text { system is a publicly available, and thus fully transparent, repository of "modules" } \\
\text { that outline Premium's mission (p. } 374 \text { ) }\end{array}$ \\
\hline \multirow[t]{2}{*}{3} & \multirow[t]{2}{*}{$\begin{array}{l}\text { Capabilities } \\
\text { and } \\
\text { competences }\end{array}$} & $\begin{array}{l}\text { Australian university - staff } \\
\text { competences } \\
\text { [Amrollahi, Rowlands 2017] }\end{array}$ & $\begin{array}{l}\text { The relatively flat organizational hierarchy and presence of well-educated and } \\
\text { literate employees were factors which could facilitate the use of the } \\
\text { crowdsourcing approach for strategic planning (p. 839). }\end{array}$ \\
\hline & & $\begin{array}{l}\text { Landcare Research, Inc. } \\
\text { (LCR) - competences in } \\
\text { communication with } \\
\text { stakeholders due to } \\
\text { fundraising experience } \\
\text { [Malhotra et al. 2017] }\end{array}$ & $\begin{array}{l}\text { LCR sets rolling five-year strategies to prioritize proposal-writing to its various } \\
\text { funding agencies (foundations, government agencies, international agencies, } \\
\text { social movements such as Predator Free New Zealand, and trusts) ... The } \\
\text { diversity of funding sources led to an increasing recognition by Landcare } \\
\text { managers of the need to involve external stakeholders in all aspects of } \\
\text { strategizing. An online OSF was felt to allow for greater representation across the } \\
\text { various stakeholders (p. } 400 \text { ). }\end{array}$ \\
\hline \multirow[t]{2}{*}{4} & \multirow[t]{2}{*}{$\begin{array}{l}\text { Expected } \\
\text { benefits }\end{array}$} & $\begin{array}{l}\text { Siemens - co-creation of } \\
\text { sustainability strategy } \\
\text { [Hutter et al. 2017] }\end{array}$ & $\begin{array}{l}\text { The chief innovation officer pointed out that maintaining an intense dialog with } \\
\text { their employees was very valuable for implementing the sustainability strategy.... } \\
\text { the expansion of the environmental product portfolio was a central theme within } \\
\text { the corporate strategy, the online platform created awareness and allowed access } \\
\text { to a wide variety of opinions and sustainable ideas (p. 360). }\end{array}$ \\
\hline & & $\begin{array}{l}\text { New ventures called Mite } \\
\text { and Buffer -impression } \\
\text { management } \\
\text { [Gegenhuber, Dobusch } \\
\text { 2017] }\end{array}$ & $\begin{array}{l}\text { As both ventures grew ... the blog audience rewarded both firms with increased } \\
\text { audience interest in open strategy-making. In both cases, open strategy blog posts } \\
\text { yield higher audience interest. Media outlets increasingly praised the move of being } \\
\text { particularly open, thereby lending additional support to each venture (p. 348). }\end{array}$ \\
\hline
\end{tabular}

Source: own research based on literature (as in the table). 
i.e. stimulate more participative approaches to strategizing [Whittington et al. 2011; Stieger et al. 2012; Aten, Thomas 2016; Hautz et al. 2017].

The significant precondition of open strategizing is the creation of an organizational culture oriented toward openness: educating employees to participate in various initiatives, empowering people offering the sense of being owners of open projects, engaging through the perception of community [Denyer et al. 2011]. Moreover, the culture of meritocracy and flexibility is expected to support engagement and participative actions. Therefore the change in organizational culture is one of the most important challenges currently facing leaders. The new leadership [Hamel 2009] relates to the expectations as to embedding the ideas of community and citizenship in management systems, sharing the work of setting direction, retooling management for an open world, and expanding the scope of employee autonomy. The trend toward greater openness in strategizing also creates a tendency for organizations to introduce less centralized forms of decision-making, as less centralized organizations are more likely to benefit from the use of inclusive practices during the open strategizing processes [Mack, Szulanski 2017].

Open strategy, undoubtedly, could be regarded as an organizational innovation. As previous research on innovation management has demonstrated, the decision about adoption and timing can vary considerably among organizations, and there are specific contextual factors shaping the adoption and implementation of innovations, e.g. organisational size and resources, history and experience in innovation and research activities, senior management commitment, established routines for handling new practices, or in general - absorptive capacity of the organization understood as its ability to recognize the value of new information, assimilate it, and apply it to commercial outcomes [Cohen, Levinthal 1990]. Due to the fact that the open strategy initiatives are conducted as projects, the significance of organizational competency in project management seems to be unquestioned. Managing crowdsourcing projects within the organization requires both the technical competences as to IT platforms, but also social competencies of engaging the internal and external actors of this endeavour. From the point of the success of the open strategy attempt it is crucial to know how the open strategy project should be led, and how its agenda should evolve with time [Chesbrough, Appleyard 2007].

Finally, the perception of the expected benefits is clearly the factor that makes organizations involved and concerned with the idea of open strategy. The first group of benefits are of a social nature. The new context of strategy - crowdsourcing, exchange of creative ideas, novel aims - is surrounded with novel social processes, such as inclusion, as well as new social outcomes such as commitment and sense of community. Thus, openness supports not only the establishment of agile and responsive firms, but also leads to the further democratization of the organization [Baptista et al. 2017]. An organizational sense of community creates particular social advantages such as membership and the feeling of belonging, the of sense that one matters, of integration, shared emotional connections, and the belief that members share history, places and time together [Hutter et al. 2017].

Open strategy can be also evaluated in terms of impression management [Gegenhuber, Dobusch 2017]. For example, new ventures could use open strategy in their interactions with external stakeholders, communicating transparently relevant information, dialoguing, asking users for opinions, engaging in conversation, and even involving external actors in decision-making. Proactive impression management contributes to an enhancement in the relationship with external stakeholders, and their endorsement for new projects and products, as well as to additional support from the media, and social media (e.g. bloggers) within.

\section{Conclusions}

Open strategy seems to be immensely corresponding to the new, complex, and multi-faced environment: filled with IT, social media, openness and social willingness to share or participate. Without doubt, the phenomenon of open strategy, borne from the idea of open innovation, has brought the merit of openness to strategic management. As the research revealed, so far the implementation of open strategy has been the subject matter of numerous and various organizations, from large companies to new ventures, from corporations to public organizations and charities.

The research presented in this paper demonstrated four major preconditions of open strategizing: social IT, open culture and leadership, organizational competences and perceived benefits. All of these preconditions could offer a new research avenue inspiring subsequent investigations as to the scope, level and impact on the opening processes in strategic management. The results of this research may also be seen as the inspiration to practitioners and supporters of the societal shift oriented to engaging employees and offering them a sense of community and satisfaction from their participation in strategic processes. Ultimately, the advantages of open strategy seem to 
induce not only better comprehension and more extensive implementation, but also common adoption in the strategic management body of knowledge.

\section{Bibliography}

Amrollahi A., Ghapnchi A.H., 2016, Open strategic planning in universities: a case study, IEEE 49th Hawaii International Conference on System Sciences.

Amrollahi A., Rowlands B., 2017, Collaborative open strategic planning: a method and case study, Information Technology \& People, vol. 30, no. 4, pp. 832-852.

Appleyard M.M., Chesbrough H.W., 2017, The dynamics of open strategy: from adoption to reversion, Long Range Planning, 50(3), pp. 310-321.

Aten K., Thomas G.F., 2016, Crowdsourcing strategizing: communication technology affordances and the communicative constitution of organizational strategy, International Journal of Business Communication, vol. 53, no. 2, pp. 148-180.

Baptista J., Wilson A.D., Galliers R.D., Bynghall S., 2017, Social media and the emergence of reflexiveness as a new capability for open strategy, Long Range Planning, vol. 50, no. 3, pp. $322-336$

Bjelland O.M., Wood R.C., 2008, An inside view of IBM's' innovation jam', MIT Sloan Management Review, vol. 50, no. 1.

Chesbrough H.W., Appleyard M.M,, 2007, Open innovation and strategy, California Management Review, vol. 50, no. 1.

Cohen W.M., Levinthal D.A., 1990, Absorptive capacity: a new perspective on learning and innovation, Administrative Science Quarterly, vol. 35, pp. 128-152

Collier N., Fishwick F., Floyd S.W., 2004, Managerial involvement and perceptions of strategy process, Long Range Planning, vol. 37, no. 1, pp. 67-83

Denyer D., Parry E., Flowers P., 2011, Social, open and participative? Exploring personal experiences and organisational effects of enterprise 2.0 use, Long Range Planning, vol. 44, no. 5-6, pp. 375-396.

Dobusch L., Kapeller J., 2017, Open strategy-making with crowds and communities: comparing Wikimedia and creative commons, Long Range Planning.

Dobusch L., Müller-Seitz G., 2012, Strategy as a practice of thousands: the case of Wikimedia, Academy of Management Best Paper Proceedings.

Gegenhuber T., Dobusch L., 2017, Making an impression through openness: how open strategy-making practices change in the evolution of new ventures, Long Range Planning, vol. 50, no. 3, pp. 337-354.
Hamel G., 2009, Moon shots for management, Harvard Business Review, vol. 872, pp. 91-98.

Hautz J., Seidl D., Whittington R, 2017, Open strategy: dimensions, dilemmas, dynamics, Long Range Planning, vol. 50, no. 3, pp. 298-309.

Heracleous L., Gosswein J., Beaudette P., 2018, Open strategy-making at the Wikimedia foundation: a dialogic perspective, Journal of Applied Behavioral Science, vol. 54, no. 1, pp. 5-35.

Hutter K., Nketia B.A., Füller J., 2017, Falling short with participation - different effects of ideation, commenting, and evaluating behavior on open strategizing, Long Range Planning, vol. 50 , no. 3 , pp. $355-370$.

Luedicke M.K., Husemann K.C., Furnari S., Ladstaetter F., 2017, Radically open strategizing: how the premium cola collective takes open strategy to the extreme, Long Range Planning, vol. 50, no. 3, pp. 371-384.

Mack D.Z., Szulanski G., 2017, Opening up: how centralization affects participation and inclusion in strategy making, Long Range Planning, vol. 50, no. 3, pp. 385-396.

Malhotra A., Majchrzak A., Niemiec R.M., 2017, Using public crowds for open strategy formulation: mitigating the risks of knowledge gaps, Long Range Planning, vol. 50, no. 3, pp. 397-410.

Mantere S., Vaara E., 2008, On the problem of participation in strategy: a critical discursive perspective, Organization Science, vol. 19, no. 2, pp. 341-358.

Newstead B., Lanzerotti L., 2010, Can you open-source your strategy? Harvard Business Review, vol. 88, np 10, pp.32-32.

Ramaswamy V., Ozcan K., 2013, Strategy and co-creation thinking, Strategy \& Leadership, vol. 41, no. 6, pp. 5-10.

Stieger D., Matzler K., Chatterjee S., Ladstaetter-Fussenegger F., 2012, Democratizing strategy, California Management Review, vol. 54, no. 4, pp. 44-68.

Tavakoli A., Schlagwein D., Schoder D., 2017, Open strategy: Literature review, re-analysis of cases and conceptualisation as a practice, The Journal of Strategic Information Systems, vol. 26 , no. 3, pp. 163-184.

Whittington R., 2015, The massification of strategy, British Journal of Management, vol. 26(S1), pp. S13-S16.

Whittington R., Cailluet L., Yakis-Douglas B., 2011, Opening strategy: evolution of a precarious profession, British Journal of Management, vol. 22, no. 3, pp.531-544.

Yakis-Douglas B., Angwin D., Ahn K., Meadows M., 2017, Opening M\&A strategy to investors: predictors and outcomes of transparency during organisational transition, Long Range Planning, vol. 50, no. 3, pp. 411-422.

\title{
OD IT DO PRZEMIAN SPOLECZNYCH: UWARUNKOWANIA OTWARTYCH STRATEGII
}

\begin{abstract}
Streszczenie: Głównym celem artykułu jest identyfikacja i analiza uwarunkowań sprzyjających skutecznemu wdrażaniu do praktyki idei otwartych strategii. Artykuł obejmuje dwie zasadnicze części: pierwsza zawiera wprowadzenie do problematyki otwartych strategii i demonstruje najważniejsze zagadnienia dotyczące tej koncepcji, część druga prezentuje wyniki badań własnych. Badania te zostały zrealizowane na podstawie przeglądu literatury przedmiotu oraz analizy źródeł wtórnych w postaci materiałów opublikowanych w ramach studiów przypadków. Na podstawie badań wskazano na cztery główne warunki wdrażania otwartych strategii: media społecznościowe, otwarta kultura organizacyjna i przywództwo, kompetencje organizacyjne i postrzegane korzyści. Zostały one nie tylko przeanalizowane, ale również zilustrowane przykładami.
\end{abstract}

Słowa kluczowe: otwarte innowacje, otwarta strategia, transparentność, włączanie, media społecznościowe. 